九州大学学術情報リポジトリ

Kyushu University Institutional Repository

\title{
A 2014 Nationwide Survey of the Distribution of Soybean Mosaic Virus (SMV), Soybean Yellow Mottle Mosaic Virus (SYMMV) and Soybean Yellow Common Mosaic Virus (SYCMV) Major Viruses in South Korean Soybean Fields, and Changes from 2012 Isolate Prevalence.
}

Li, Meija

Department of Applied Biology, College of Agriculture and Life Sciences, Chungnam National University

Seo, Eun-Young

Department of Applied Biology, College of Agriculture and Life Sciences, Chungnam National University

Cho, Seunghee

Department of Applied Biology, College of Agriculture and Life Sciences, Chungnam National University

Kim, Jungkyu

Department of Applied Biology, College of Agriculture and Life Sciences, Chungnam National University

他

https://doi.org/10.5109/1526393

出版情報：九州大学大学院農学研究院紀要. 60 (2)，pp.339-347，2015-09-18. Faculty of Agriculture, Kyushu University

バージョン :

権利関係 : 


\title{
A 2014 Nationwide Survey of the Distribution of Soybean Mosaic Virus (SMV), Soybean Yellow Mottle Mosaic Virus (SYMMV) and Soybean Yellow Common Mosaic Virus (SYCMV) Major Viruses in South Korean Soybean Fields, and Changes from 2012 Isolate Prevalence.
}

\author{
Meijia LI ${ }^{1 a}$, Eun-Young SEO ${ }^{1 a}$, Seunghee CHO $^{1}$, Jungkyu KIM${ }^{1}$, Jinsoo CHUNG ${ }^{1}$, \\ Hyo-Jin LIM ${ }^{1}$, Takafumi GOTOH, John HAMMOND ${ }^{2}$, Hyoun-Sub LIM* ${ }^{1 *}$
}

\author{
Kuju Agricultural Research Center, Faculty of Agriculture, \\ Kyushu University, Kuju, Oita, 878-0201, Japan \\ (Received May 8, 2015 and accepted May 19, 2015)
}

\begin{abstract}
In 2014 symptomatic soybean samples were collected throughout Korea, and were tested for the most important soybean viruses found in Korea, namely Soybean mosaic virus (SMV), Soybean yellow common mosaic virus (SYCMV), and Soybean yellow mottle mosaic virus (SYMMV). SYMMV was most commonly detected, followed by SMV. Only a few samples were found to be infected by SYCMV; of these, three samples were positive for double infection of SYMMV and SYCMV. Phylogenetic analysis of HC-Pro of the SMV isolates collected in 2014 from the eight provinces of Korea showed that most isolates were distinct from the most common Korean isolate detected in 2012, but related to other Korean, Chinese and North American isolates. No isolates varying in HC-Pro amino acid residues implicated in efficiency of RNA silencing suppression activity were detected in 2014. Phylogenetic analysis of ORF1 of both 2012 and 2014 SYCMV isolates showed differentiation into three subgroups. However, the geographical distribution of all three viruses in 2014 was essentially the same as observed in 2012. Quantitative real time PCR data also indicated a similar pattern of dual infected viruses occurrence as existed in 2012. Results showed SMV/ SYMMV double infection RNA accumulation was not changed as much as SYMMV/SYCMV double infection. However, between double infection SMV/SYMMV, SYMMV RNA accumulation level rises more than SMV, and SYCMV RNA accumulation level decline a little compare with SYMMV. In summary, the 2014 survey showed that SMV and SYMMV are still the most prevalent soybean viruses in Korea, and all three viruses were still dispersed in the same areas where they were detected in 2012, although with an apparent shift towards SMV Group I isolates compared to 2012. The reason for the shift in SMV isolates across all Korean provinces is not clear, as seed transmission through farmer-saved seed is presumed to be the main source of infection within the crop.
\end{abstract}

Key words: Double infection, Soybean mosaic virus, Soybean yellow common mosaic virus, Soybean yellow mottle mosaic virus, Virus survey

\section{INTRODUCTION}

Soybean (Glycine max (L.) Merrill) originated from East Asia, and is a natural host to more than 30 plant viruses (Demski et al., 1989). Eight of these soybean virus species were already found in Korea, including Alfalfa mosaic virus (AMV), Cowpea mosaic virus (CPMV), Cucumber mosaic virus (CMV), Soybean dwarf virus (SbDV), Soybean mosaic virus (SMV), Soybean yellow common mosaic virus (SYCMV), Soybean yellow mottle mosaic virus (SYMMV), and Peanut stunt virus (PSV) (Nam et al., 2009; Nam et al., 2011; Baek et al., 2012). Among them, SMV is one of the most prevalent pathogens of soybean (Hill, 1999). SYMMV and SYCMV are recently discovered viruses first detected in Korea (Nam et al., 2009; Nam et al., 2011). SYMMV was shown to be a member of the genus Carmovirus family Tombusviridae (Nam et al., 2009); SYCMV belongs to the genus Sobemovirus (Nam et al.,

\footnotetext{
Department of Applied Biology, College of Agriculture and Life Sciences, Chungnam National University, Daejeon 305-764, Korea

Floral and Nursery Plants Research Unit, US National Arboretum, USDA-ARS, Beltsville, MD 20705, USA

1* Corresponding Author (E-mail: hyounlim@cnu.ac.kr)

a These two authors contributed equally to this work
}

2011). SMV is a member of the genus Potyvirus, family Potyviridae (Cho and Chung, 1976). AMV is a member of the genus Alfamovirus, the family Bromoviridae (Bol, J. F. 2005), and CPMV of the genus Comovirus, family Comoviridae (Green et al., 2009). CMV belongs to the Cucumovirus genus in the family Bromoviridae (Van Regenmortel et al., 2000), while SbDV is a member of the genus Luteovirus, family Luteoviridae (Terauchi et al., 2001) and PSV is in the genus Cucumovirus, family Bromoviridae (Diaz-Ruiz et al., 1983).

In Korea most soybeans are grown on small farms, and most of the smallholder farmers save their own seed for replanting. This may lead to the seed acting as the largest source of primary inoculum for the new crops. However, there are also wild legumes including other Glycine species growing in Korea that may serve as reservoirs of SMV between seasons, and as sources of different isolates. Some seed is also imported from other countries, including the United States, as a source of new varieties. Surveys of virus prevalence and isolate differences over time will help to differentiate between these possibilities.

In a 2012 survey of 682 Korean soybean samples, Cho et al reported that most were infected by SMV (15\%) or SYMMV (17\%) and few are infected by SYCMV (2.4\%) (Cho et al., 2013). One SMV isolate detected during the 
2012 survey was found to have a very weak silencing suppressor HC-Pro due to substitutions of three amino acids (Li et al., 2013). Others have reported that SMV caused the most severe (more than $90 \%$ in the past) damage in Korea, while more recently viruses like SYMMV, SYCMV, SbDV and PSV have been reported (Baek et al., 2012). Two other 2012 surveys reported detection of five kinds of viruses (SMV, PSV, SYCMV, SYMMV, and BCMV) with SMV and SYMMV found to be the most prevalent in this survey (Baek et al., 2012; Lim, 2013).

Following a 2012 nationwide survey Cho et al. (2013) suggested self-managed seed production might result in seed transmission as the primary source of inoculum in the crop. Typically, seed transmitted SMV is no longer detected in the US (Hill, 1999) as a result of screening by seed companies. HC-Pro of SMV functions as a silencing suppressor (Hill, 1999) and also in seed transmission (Blanc et al., 1997; Peng et al., 1998). The domains of HC-Pro are highly conserved in highly seed transmitted SMV (Domier et al., 2011), while HC-Pro conserved amino acid sequence motifs (KITC and PTK) are required for aphid transmission. (Atreya et al., 1990; Blanc et al., 1997; Peng et al., 1998). Virus seed transmission has different selection pressures than aphid transmission; seed transmission is mainly dependent on the seed genotype (Domier et al., 2011), and pathogen virulence is not a selective advantage for seed transmission (Bergstrom $e t$ $a l ., 1999)$. In this report we performed a nationwide survey including all of the same regions as were examined in 2012. Through this work we have generated information to explain why soybean viruses occur in Korean soybean fields, and to note the importance of managing viral diseases and seed control through regular farmer education.

\section{MATERIALS AND METHODS}

Collection of virus infected plant materials. Soybean samples with virus symptoms were collected nationwide. A total of 251 soybean tissue samples were collected in 2014 from infected soybean plants from fields in all eight Korean provinces (Fig. 1). 48 samples were collected from North Gyeongsang, and 21 samples from South Gyeongsang. 36 samples were collected in North Jeolla, and 37 samples in South Jeolla. 29 samples were from Gangwon, and 30 samples from Gyeonggi, 30 samples from South Chungcheong, 20 samples from North Chungcheong (Fig. 1).

RNA extraction, RT-PCR detection, and sequencing. Total RNA was extracted from each of 251 collected plant samples using TRIzol (Invitrogen, Rockville, MD) according to the manufacturer's recommendations. Individual RNA samples were used as template to synthesize cDNA, using M-MLV reverse transcriptase according to the manufacturer's recommendations (Enzynomics, Korea). RT-PCR for detection of SMV, SYMMV, and SYCMV was performed using the primers listed in Table 1, yielding products of $890 \mathrm{bp}, 597 \mathrm{bp}$, and $346 \mathrm{bp}$ respectively (Cho et al., 2013). Primers for amplification of SMV HC-Pro were designed based on reference sequence NC_016033
(Li et al., 2013), and for SYCMV ORF1 based on NC_002634 from National Center for Biotechnology Information (NCBI) (Table 1) for PCR using high-fidelity Blend Taq polymerase (Toyobo Co., Ltd) followed manufacturer's recommendations. Amplification products were cloned in the TOPO blunt vector (Enzynomics, Korea); a minimum of five clones for each isolate were sequenced (Macrogen, Seoul, Korea). No variation was observed among clones of an isolate. One clone from each isolate was selected for further analysis.

Quantitative real-time PCR. Quantitative real-time PCR (Q-RT-PCR) was utilized to compare accumulation of double infection SMV/SYMMV and SYMMV/SYCMV RNA (primers QRT-SMV F, R; QRT-SYMMV F, R; QRTWYCMV F, R Table 1) accumulation in infected soybean plants. Total RNA was extracted from plant tissues using an RNeasy Plant Mini Kit (QIAGEN, Hilden, Germany) according to the manufacturer's recommendations, and cDNAs were synthesized using M-MLV reverse transcriptase as described above. Internal standard primers were designed for the Tubulin RNA of soybean (GenBank accession no. NM_001250372 Tubulin F and R). Q-RTPCR was performed with SsoAdvanced SYBR Green Supermix (Bio-Rad Laboratories, CA). Each 20- $\mu$ l reaction contained $10 \mu \mathrm{l}$ SsoAdvanced SYBR Green Supermix, $5 \mu \mathrm{l} 40$-fold-diluted cDNA, $10 \mathrm{pM}$ each gene-specific primer. Reaction conditions were $95^{\circ} \mathrm{C}$ for $10 \mathrm{~min} ; 40$ cycles of $95^{\circ} \mathrm{C}$ for $30 \mathrm{~s}, 58^{\circ} \mathrm{C}$ for $20 \mathrm{~s}, 72^{\circ} \mathrm{C}$ for $30 \mathrm{~s}$. Transcript levels of double infection SMV/SYMMV CP, SYMMV/SYCMV CP were normalized to SYMMV, respectively. Soybean tubulin was used as an internal standard. Mean values were calculated from two biological replications (Bae et al., 2006). Statistical analysis of Q-RT-PCR results was carried out using Microsoft Excel to separate reactions into classes.

Phylogenetic analysis. To examine the relationships of SMV and SYCMV isolates between 2012 and 2014, phylogenetic analyses were performed on SMV HC-Pro and SYCMV ORF1 sequences (Fig. 2 and Fig. 3). SYMMV sequences from 2012 were not available. Nucleotide sequences were aligned using Clustal X2 (Thompson et al., 1997) and manually edited. Maximum-likelihood (ML) and maximum-parsimony (MP) analyses were implemented with MEGA v 5.05 (Tamura et al., 2011). Each MP analysis was carried out by a heuristic search with 1000 random stepwise additions of branches to obtain bootstrap values. The nucleotide sequence of watermelon mosaic virus (NC_006262) HC-Pro was used as outgroup to root SMV trees; SMV HC-Pro sequences from 2012 were previously examined (Li et al., 2013). The HC-Pro nucleotide sequence of SMV isolate A29712 was used as an outgroup to root the tree of SYSMV ORF1.

\section{RESULTS}

SMV, SYMMV, and SYCMV were dispersed nationwide. We collected 251 soybean samples from suspected virus infected soybean based on symptom development. As indicated in Figure 1 we collected samples across the 

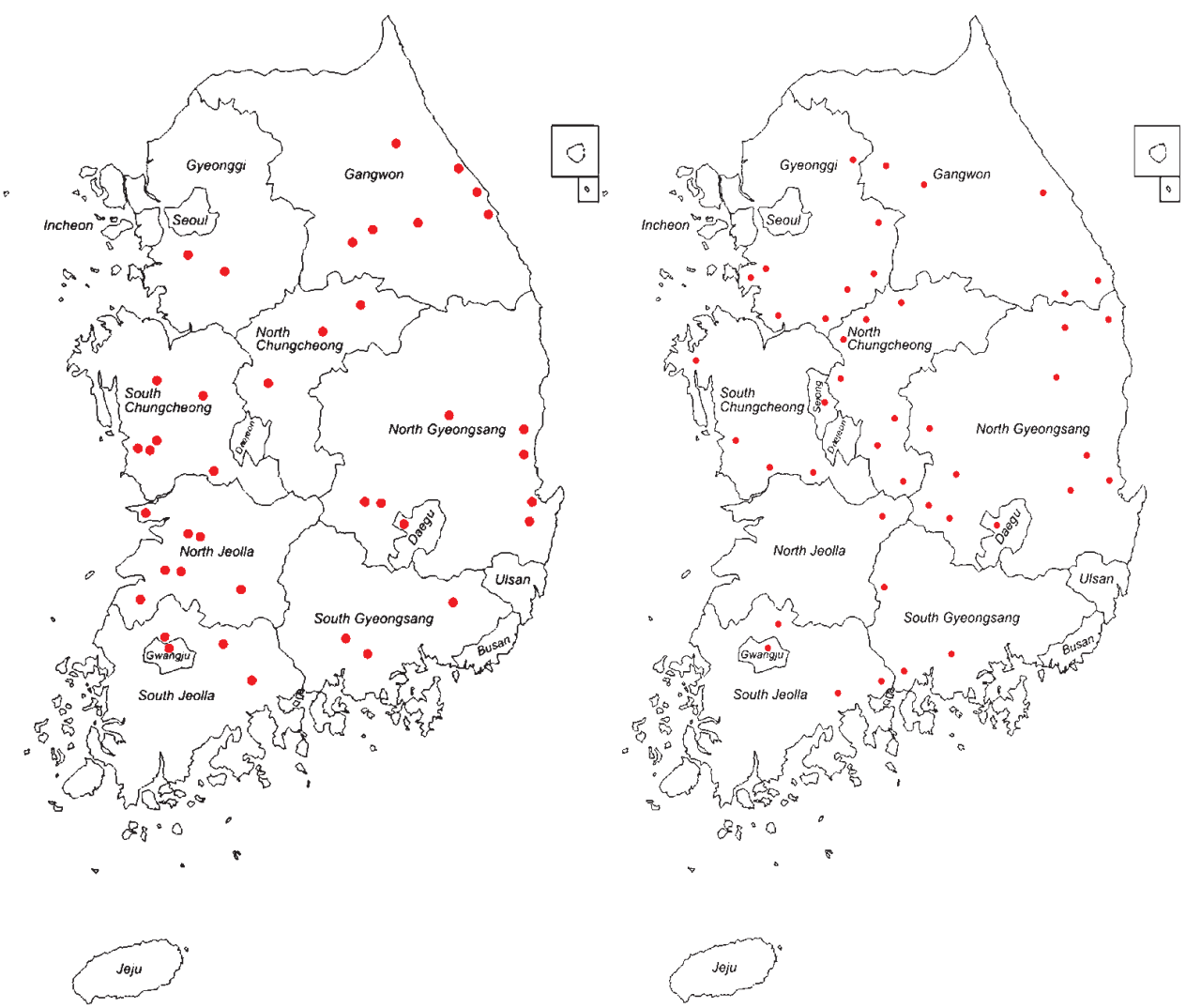

Fig. 1. Geographical distribution of collection sites of soybean samples (Left:2014, Right:2012).

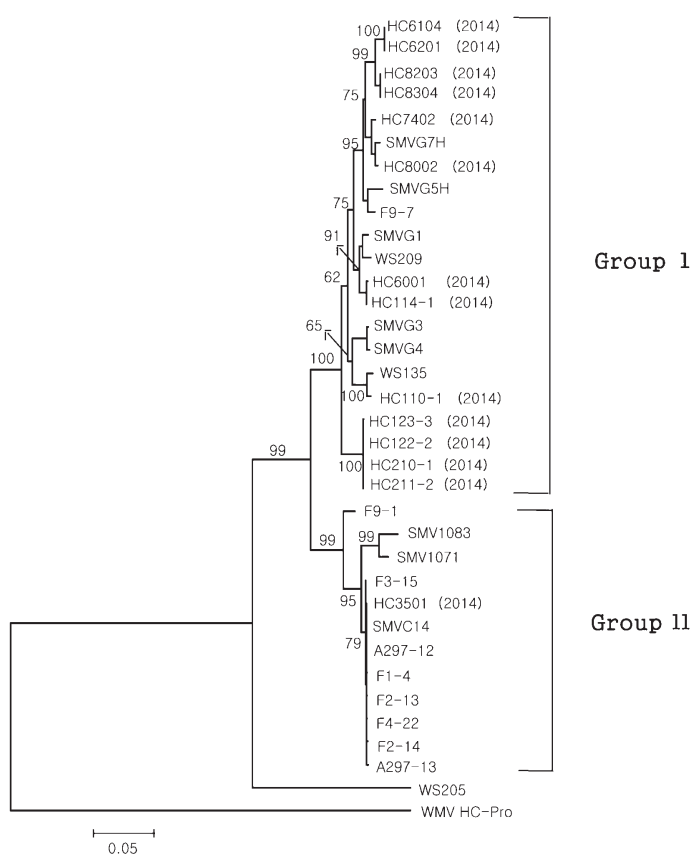

Fig. 2. The most parsimonious tree based on the HC-Pro nucleotide sequences of 39 SMV strains. Bootstrap values greater than $50 \%$ calculated from 1000 replicates are given at the nodes. The scale bar indicates the number of nucleotide substitutions. HC-Pro sequences from 2014 isolates: HC6104 isolate B61, HC6201 isolate B62, HC8203 isolate B82, HC8304 isolate B83, HC7402 isolate B74, HC8002 isolate B80, HC6001 isolate B60, HC114-1 isolate B114, HC110-1 isolate B110, HC210-1 isolate B210, HC211-2 isolate B211, HC3501 isolate B35. All other HC-Pro sequences are reference isolates or 2012 Korean isolates described in Li et al., (2014).

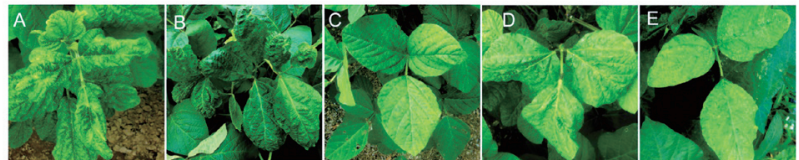

Fig. 3. Typical symptoms of virus-infected soybeans: (A) Soybean mosaic virus infected plants (B) Soybean yellow mottle mosaic virus infected plants (C) Soybean yellow common mosaic virus infected plants (D) Soybean mosaic virus, Soybean yellow mottle mosaic virus double infected plants (E) Soybean yellow mottle mosaic virus, Soybean yellow common mosaic virus double infected plants.

same regions in which we performed the survey in 2012 (Cho et al., 2013). RT-PCR data showed that fifty-three tissue samples were positive for SMV, six samples for SYCMV and 67 for SYMMV (Table 2 and Table 3). Among these samples B82 was positive for both SMV and SYMMV, and B183/B184/B185 were positive for both SYCMV and SYMMV (Table 4). B82 was collected in North Gyeongsang and B183/B184/B185 were from Gangwon. Compared to the survey performed in 2012, SMV/SYMMV dual infections, and SMV/SYCMV dual infection were found but not SYMMV and SYCMV (Table 4). In 2014 survey, one sample was infected by SMV and SYMMV, and three samples were infected with both SYMMV and SYCMV.

Plants dually infected by SMV+SYMMV or SYMMV+ SYCMV did not show severe symptoms, however singly infected soybean produced severe symptoms regardless of which virus was present. Leaves with single infection 
Table 1. Nucleic acid sequence of oligonucleotide primers used in this study

\begin{tabular}{|c|c|c|c|}
\hline Virus & Accession No. & Sequence of Primer & PCR region \\
\hline $\mathrm{SMV}_{\mathrm{a}}$ detection & GU015011 & $\begin{array}{l}\text { GAACAAAGCAAGATAGCATG } \\
\text { TGTGTAGACTATCTCAGCAT }\end{array}$ & $\mathrm{NIb}$ \\
\hline $\mathrm{SYMMV}_{\mathrm{b}}$ detection & NC_011643 & $\begin{array}{l}\text { CAACCCTCAGCCACATTCAACTAT } \\
\text { TCTAACCACCCCACCCGAAGGATT }\end{array}$ & ORF5 \\
\hline SYCMV $_{c}$ detection & NC_016033 & $\begin{array}{l}\text { TTGGCTGAGAGGAGTGGCTT } \\
\text { TGCGGTCGTGTAGTCAGTG }\end{array}$ & $\mathrm{CP}$ \\
\hline SMV HC-Pro (F, R) & GU015011 & $\begin{array}{l}\text { ATGTCCCAAAATCCTGAAGCTCAG } \\
\text { TTATTCACCACCAACTCTGTAGAATTTC }\end{array}$ & HC-Pro \\
\hline SYCMV ORF1(F, R) & NC_016033 & $\begin{array}{l}\text { ATGACCGACACAGTCGTCGTG } \\
\text { TCACGACCAAGAGCGTGTACGCAAA }\end{array}$ & ORF1 \\
\hline QRT-SMV(F, R) & GU015011 & $\begin{array}{l}\text { AAAACACCAAACAGGGCAAG } \\
\text { TGGTTGAGATGTTCCCATCA }\end{array}$ & $\mathrm{CP}$ \\
\hline QRT-SYMMV (F, R) & NC_011643 & $\begin{array}{l}\text { TGTGTCCAATGGAGTACCGA } \\
\text { AAGCAGGGGACTCAGTGCTA }\end{array}$ & $\mathrm{CP}$ \\
\hline QRT-SYCMV (F, R) & NC_016033 & $\begin{array}{l}\text { ATGCTAACATCGCGACTCCT } \\
\text { GTTCAAGGCTGAGGCGATAG }\end{array}$ & $\mathrm{CP}$ \\
\hline QRT-Tubulin (F, R) & NM_001250372 & $\begin{array}{l}\text { TCTCTCGCATTGACCACAAG } \\
\text { CACGAGCCTCAGAAAACTCC }\end{array}$ & Tubulin \\
\hline
\end{tabular}

${ }^{\text {a }}$ Soybean mosaic virus

${ }^{\mathrm{b}}$ Soybean yellow mottle mosaic virus

${ }^{\mathrm{c}}$ Soybean yellow common mosaic virus

Table 2. Incidence of viruses detected during 2012 and 2014 in Korea

\begin{tabular}{ccc}
\hline Virus & $2012 \%$ incidence & $2014 \%$ incidence \\
\hline SMV & $100 / 682$ & $52 / 251$ \\
SYMMV & $116 / 682$ & $67 / 251$ \\
SYCMV & $17 / 682$ & $6 / 251$ \\
SMV+SYMMV & $5 / 682$ & $1 / 251$ \\
SMV+SYCMV & $1 / 682$ & - \\
SYMMV+SYCMV & - & $3 / 251$ \\
\hline
\end{tabular}

Table 3. Virus infected samples collected in 2012 and 2014 in eight Provinces of Korea

\begin{tabular}{|c|c|c|c|c|c|c|}
\hline \multirow{2}{*}{$\begin{array}{l}\text { Viruses infection } \\
\text { Provinces }\end{array}$} & \multicolumn{2}{|c|}{ SMV } & \multicolumn{2}{|c|}{ SYMMV } & \multicolumn{2}{|c|}{ SYCMV } \\
\hline & 2012 & 2014 & 2014 & 2014 & 2012 & 2014 \\
\hline South Gyeongsang & + & + & + & + & + & - \\
\hline Nouth Gyeongsang & + & + & + & + & + & - \\
\hline South Chungcheong & - & + & + & + & + & - \\
\hline North Chungcheong & + & + & + & + & + & + \\
\hline South Jeolla & + & + & + & - & - & - \\
\hline North Jeolla & + & + & + & + & - & + \\
\hline Gyeonggi & + & + & + & + & + & + \\
\hline Gangwon & + & + & + & + & + & + \\
\hline
\end{tabular}


Table 4. Locations of virus infection of soybean samples

\begin{tabular}{|c|c|c|c|c|c|}
\hline \multirow{2}{*}{ Sample No. } & \multirow{2}{*}{ Localization } & \multirow{2}{*}{ Date } & \multicolumn{3}{|c|}{ Viruses identified } \\
\hline & & & SMV & SYCMV & SYMMV \\
\hline $\mathrm{B} 2, \mathrm{~B} 3, \mathrm{~B} 4$ & Dalseong-gun, Daegu & 2014-06-14 & & & $\bullet$ \\
\hline B6 & Seosan & 2014-06-18 & & & $\bullet$ \\
\hline B18 & Jeongeup & 2014-06-25 & & & $\bullet$ \\
\hline B25 & Damyang-gun & 2014-06-25 & $\bullet$ & & \\
\hline B31 & Cheonan & $2014-07-01$ & & & $\bullet$ \\
\hline B35 & Cheonan & 2014-07-01 & $\bullet$ & & \\
\hline $\begin{array}{l}\text { B38, B40, B41, B42, } \\
\text { B43, B44 }\end{array}$ & Yesan & 2014-07-04 & & & $\bullet$ \\
\hline B47 & Cheongyang & 2014-07-04 & & & $\bullet$ \\
\hline $\begin{array}{l}\text { B51, B52, B53, B54, } \\
\text { B55, B57 }\end{array}$ & Chungju & 2014-07-10 & & & $\bullet$ \\
\hline B60 & Chungju & 2014-07-13 & $\bullet$ & & \\
\hline B61, B62 & Jeonju & 2014-07-13 & $\bullet$ & & \\
\hline B63 & Jeonju & 2014-07-13 & & $\bullet$ & \\
\hline $\mathrm{B} 71, \mathrm{~B} 72, \mathrm{~B} 73$ & Jinju & $2014-07-15$ & & & $\bullet$ \\
\hline $\begin{array}{l}\text { B74, B75, B76, B77, } \\
\text { B78, B79,B80 }\end{array}$ & Sancheong & $2014-07-15$ & $\bullet$ & & \\
\hline B81, B83, B84, B85 & Gimcheon & 2014-07-18 & $\bullet$ & & \\
\hline B82a & Gimcheon & 2014-07-18 & $\bullet$ & & $\bullet$ \\
\hline B86, B87 & Gimcheon & 2014-07-18 & $\bullet$ & & \\
\hline $\mathrm{B} 102,103,106$ & Icheon & 2014-07-21 & & & $\bullet$ \\
\hline $\begin{array}{l}\text { B108, B110, B111, B112, } \\
\text { B114 }\end{array}$ & Icheon & 2014-07-21 & $\bullet$ & & \\
\hline B113 & Icheon & $2014-07-21$ & & $\bullet$ & \\
\hline B118, B119 & Donghae & $2014-07-28$ & & & $\bullet$ \\
\hline $\begin{array}{l}\text { B122, B123, B125, B127, } \\
\text { B128 }\end{array}$ & Yeongwol & 2014-07-28 & $\bullet$ & & \\
\hline B124 & Yeongwol & 2014-07-28 & & & $\bullet$ \\
\hline B129, B132 & Yeongwol & 2014-07-28 & & & $\bullet$ \\
\hline B134 & Jecheon & 2014-07-28 & & $\bullet$ & \\
\hline B135, B137 & Jecheon & 2014-07-28 & & & $\bullet$ \\
\hline $\begin{array}{l}\text { B138, B139, B140, B141, } \\
\text { B142,B143 }\end{array}$ & Buyeo & 2014-07-31 & & & $\bullet$ \\
\hline B150 & Gyeongju & 2014-08-07 & $\bullet$ & & \\
\hline B154, B158, B159 & Yeongdeok & 2014-08-07 & & & $\bullet$ \\
\hline B161, B162, B163 & Ulgin & 2014-08-07 & & & $\bullet$ \\
\hline B166, B168 & Samcheok & 2014-08-07 & & & $\bullet$ \\
\hline $\begin{array}{l}\text { B169, B172, B173, B174, } \\
\text { B178vB179, B180 }\end{array}$ & Ansan & 2014-08-07 & & & $\bullet$ \\
\hline B171 & Ansan & 2014-08-07 & $\bullet$ & & \\
\hline B181, B182 & Yanggu & 2014-08-07 & $\bullet$ & & \\
\hline B183, B184, B185 & Yanggu & 2014-08-07 & & $\bullet$ & $\bullet$ \\
\hline B186, B187 & Yanggu & 2014-08-07 & & & $\bullet$ \\
\hline B192 & Eumseong & 2014-08-07 & & & $\bullet$ \\
\hline B198, B200-202 & Miryang & 2014-08-20 & $\bullet$ & & \\
\hline B209-B224 & Gurye & 2014-08-27 & $\bullet$ & & \\
\hline B239-242, B244, B246 & Jeongeup & 2014-08-27 & & & $\bullet$ \\
\hline
\end{tabular}


of each of SMV, SYMMV and SYCMV showed severe mosaic, with curling margins (Fig. 4). In order to determine the relationship between virus concentration and symptoms caused by double infection we performed Q-RT-PCR to quantify individual virus RNA copy number. Results showed SMV/SYMMV double infection RNA accumulation was not changed as much as SYMMV/ SYCMV double infection. However, between double infection SMV/SYMMV, SYMMV RNA accumulation level rises constantly higher more than SMV, and SYCMV RNA accumulation level declined a little compare with SYMMV (Table 5).

Phylogenetic analysis (ML and MP methods) of HCPro of 14 representative new SMV isolates. Comparison of new Korean isolates with previously characterized strains from China, Korea or North America showed that the SMV HC-Pro sequences were divided into two groups (Fig. 2 and Table 6). Most U.S. strains clustered (100\% bootstrap support) in group I, together with most of the Korean isolates collected in 2014. As results from ML and MP analyses were similar, only MP analyses are further described. Only one of the new isolates fell into group II (99\% bootstrap support) with one previously characterized Chinese isolate (C14) and most of the 2012 Korean SMV isolates. Phylogenetic analysis results showed that the HC-Pro sequences of most of the SMV isolates that we collected in 2014 were not similar to the isolates collected in 2012, including the SMV/SYMMV double infection isolate B 82; the majority were instead similar to American, Chinese and other reference isolates (Domier et al., 2003; Lim 1985; Li et al., 2013). Isolate B82 came from the same region as 2012 double infection SMV/SYMMV isolate A 269, from North Gyeongsang Province.

Amino acid alignment of SMV HC-Pro isolates between 2012 and 2014. We have previously identified differences of one 2012 isolate at HC-Pro amino acid residues 54, 286, 369 which we predicted were related to efficiency of HC-Pro silencing suppressor activity (Li et al., 2013). Alignment of HC-Pro amino acid sequences showed that all of the 2014 isolates were identical at these positions to the majority of 2012 isolates; only 2012 isolate A297-13 was different at these three positions (Li et al., 2013; and data not shown).

Analysis of SYMMV and SYCMV. Comparison of new isolates from 2014 with previously characterized isolates

Table 5. Real-time qPCR of soybeans double infected with between Soybean mosaic virus (SMV) / Soybean yellow mottle mosaic virus (SYMMV) and SYMMV / Soybean yellow common mosaic virus (SYCMV)

\begin{tabular}{ccccc}
\hline Location & SMV/SYMMV & & SYMMV/SYCMV & B185 \\
\cline { 3 - 5 } Samples & B82 & B183 & B184 & 5.42 \\
\hline${\text { ct } 1^{\mathrm{a}}}^{\Delta \text { ct2 }^{\mathrm{b}}}$ & 2.46 & 0.84 & 2.46 & 9.33 \\
$\Delta \Delta$ ct3 $^{\mathrm{c}}$ & -7.93 & 5.08 & 7.89 & $-3.91(0.0665)$ \\
\hline
\end{tabular}

${ }^{a} \Delta \mathrm{ct}_{1}$ (ct value of tubulin - ct value of SYMMV or SYCMV).

${ }^{\mathrm{b}} \mathrm{ct}_{2}$ (ct value of tubulin - ct value of SMV or SYMMV).

${ }^{c} \Delta \Delta$ ct shows value of $\Delta \mathrm{ct}_{1}-\Delta \mathrm{ct}_{2}$.

Table 6. Country of origin and GenBank accession numbers of SMV HC-Pro nucleotide sequences used for comparisons

\begin{tabular}{lcc}
\hline SMV strain/isolate & Origin & GenBank accession No. \\
\hline HC3501 (2014) & Korea (South Chungchong) & KM650173 \\
HC6001(2014) & Korea (North Chungchong) & KM650174 \\
HC6104 (2014) & Korea (North Jeolla) & KM650175 \\
HC6201 (2014) & Korea (North Jeolla) & KM650176 \\
HC7402 (2014) & Korea (South Gyeongsang) & KM650177 \\
HC8002 (2014) & Korea (South Gyeongsang) & KM650178 \\
HC8203 (2014) & Korea (North Gyeongsang) & KM650179 \\
HC8304 (2014) & Korea (North Gyeongsang) & KM650180 \\
HC110-1 (2014) & Korea (Gyeonggi) & KM650181 \\
HC114-1 (2014) & Korea (Gyeonggi) & KM650182 \\
HC122-2 (2014) & Korea (Gangwon) & KM650183 \\
HC123-3 (2014) & Korea (Gangwon) & KM650184 \\
HC210-1 (2014) & Korea (South Jeolla) & KM650185 \\
HC211-2 (2014) & Korea (South Jeolla) & KM650186 \\
WMV & France & NC_006262
\end{tabular}


Table 7. Region of origin in Korea and GenBank accession numbers of SYCMV ORF1 nucleotide sequences used for comparisons

\begin{tabular}{ccc}
\hline SYCMV strain/isolate & Region of origin & GenBank accession No. \\
\hline $1-1$ & Gyeonggi & KM881452 \\
$1-1-3$ & Gyeonggi & KM881453 \\
$1-1-4$ & Gyeonggi & KM881454 \\
$1-2-2$ & South Chungcheong & KM881455 \\
$1-2-3$ & South Chungcheong & KM881456 \\
$1-2-4$ & South Chungcheong & KM881457 \\
$1-3-3$ & North Chungcheong & KM881458 \\
$1-3-4$ & North Chungcheong & KM881459 \\
$1-3-5$ & North Chungcheong & KM881460 \\
$1-4-2$ & Gangwon & KM881461 \\
$1-4-3$ & Gangwon & KM881462 \\
$1-4-4$ & Gangwon & KM881463 \\
$1-5-1$ & South Gyeongsang & KM881464 \\
$1-5-2$ & South Gyeongsang & KM881465 \\
$1-5-4$ & South Gyeongsang & KM881466 \\
B113 (2014) & Gyeonggi & KM881462 \\
B134 (2014) & North Chungcheong & KM881463 \\
B183 (2014) & Gangwon & KM881464 \\
B184 (2014) & Gangwon & KM881465 \\
B185 (2014) & KM881466 \\
\hline
\end{tabular}

from 2012 showed that the SYCMV ORF1 sequences were divided into three groups (Fig. 3 and Table 7) correlating with geographical origin. Group I including north part of Korea (Gyeonggi, Gangwon), 2014 survey double infection SYMMV, SYCMV No. 183-185 from Gangwon province together with 2012 single SYCMV infection isolates 1-4-1, 1-4-2, 1-4-3 from northern Gangwon Province clustered (67\% bootstrap support) in group I. Group II contains single infection of SYCMV No. 113 and 134 from the middle part of Korea (North Gyeongsang, South Gyeongsang and North Chungcheong), together with 2012 isolates. Group III included only 2012 isolates from the south part of Korea (South Gyeongsang) (Fig. 3).

\section{DISCUSSION}

We compared the distribution of the three main soybean viruses - SMV, SYMMV and SYCMV - in Korea in 2014 to their distribution in 2012. During this survey, results showed SYMMV and SMV were the most prevalent viruses in 2014, and few SYCMV isolates were detected, just as observed in 2012 (Cho et al., 2013). A few double infections of SMV/SYMMV, and SYMMV/ SYCMV were detected, whereas in 2012 no SYMMV/ SYCMV double infections were detected (Cho et al., 2013). Phylogenetic analysis of SMV HC-Pro showed that the most of the 2014 isolates were of a different subgroup than most 2012 isolates. However, amino acid alignment of domains associated with RNA silencing suppression efficiency (Li et al., 2013) showed there were no differences within any 2014 isolates; HC-Pro residues 54, 286 and 369 were important for the virus to maintain high silencing suppressor activity (Li et al., 2013). In order to examine the relationship between symptoms and double infection we performed Q-RT-PCR to quantify RNA copy number of each virus. Results showed SMV/SYMMV double infection RNA accumulation was not changed as much as SYMMV/SYCMV double infection. However, between double infection SMV/SYMMV, SYMMV RNA accumulation level was higher more than SMV, and SYCMV RNA accumulation level declined a little compare with SYMMV (Table 4).

In past few years, many studies have been performed to study the soybean virus incidence in Korea. Cho et $a l$. reported that the most prevalent soybean viruses in Korea are SMV and SYMMV, with a few double infections of SMV/SYMMV and SMV/SYCMV also being detected (Cho et al., 2013). Our 2014 results were consistent with the prior report that SMV and SYMMV are the main viruses infecting soybean plants. Symptoms of single infection of SMV, SYMMV and SYCMV were severe mosaic and curling leaves, but double infection of SMV/SYMMV, SYMMV/SYCMV did not produce symptoms as severe as the single virus infections. Our 2014 results showed that single infection of SMV and SYMMV were still prevalent to the same extent as our earlier study, with similar symptom expression. However, phylogenetic analysis showed a difference in the type of SMV isolates between 2012 and 2014, and no variation in residues linked to less efficient silencing suppression activity of HC-Pro was detected. Distribution of SYCMV in 2014 was consistent with that observed in the 2012 study and there was little 
evidence from the phylogenetic analysis for significant change in the distribution of types of isolates, although no group III isolates were detected in 2014. Plants with double infections of SYMMV/SYCMV showed apparent aphid feeding damage that suggests that aphid control may be needed to minimize SYCMV transmission.

We have shown here that SMV, SYMMV and SYCMV occurred with about the same frequency in 2014 as we previously observed in 2012 (Cho et al., 2013), across all of the Korean provinces examined. However, we have observed a shift in the types of isolate of SMV between 2012 (predominantly group II) and 2014 (predominantly group I). The reason for the apparent shift in SMV isolate type across all regions of Korea is unknown, but calls into question some prior assumptions. Because many or most small-scale soybean farmers in Korea save their own seed for replanting, it has been widely assumed that SMV seed transmission was responsible for most of the initial inoculum in the crop. There are no major suppliers of soybean seed within Korea, but some farmers do periodically obtain fresh sources of seed, typically from the United States. Unfortunately, we did not obtain information about seed sources or varieties at the time of either the 2012 or 2014 sample collections, and thus cannot determine whether there has been a significant turnover in varieties between the two surveys. One other possible explanation for our observations is that a new isolate had been introduced or evolved that either replicates to higher levels (providing more inoculum for aphid transmission) or is more efficiently aphid- (or seed-) transmitted than the isolates predominating in our 2012 survey; this seems somewhat unlikely, as the group I isolates were widely distributed both geographically in multiple Korean provinces, and also appear within multiple clades within group I suggesting variation developing over a considerably longer period than the two years between our surveys. Yet a third possibility is transmission from wild or weedy hosts of SMV spurred by climatic conditions that encouraged atypical movement of a vector between infected wild hosts and cultivated soybean over all of the provinces surveyed; while this scenario seems unlikely, a survey for SMV infection in wild Glycine species and other wild legumes would address the question of the distribution and variability of SMV in non-crop species. Lee and Kim (2013) have already demonstrated that wild soybean $(G$. soja), Vigna angularis, Trifolium repens, and Lespedeza cuneata are naturally weed hosts of SYMMV, and there is thus a possibility that these or other wild legumes are also reservoirs of various isolates of SMV, potentially causing the observed shifts in isolates detected in cultivated soybean between 2012 and 2014. We previously reported that during the survey period of May to October, there were more SYCMV detections during the later part of the period than during the early stage (Cho et al., 2013). In this study, more SYCMV infections were detected after July than were identified before July. How and why this happened will need additional study, but suggests transmission of SYCMV within and between fields by an aerial vector. SMV infection has been reported to occur by both seed and aphid transmission
(Browers and Goodman, 1991; Domier et al., 2007; Seo et al., 2010). SYMMV could be infected by seed transmission, and SYMMV infection of wild soybean populations was notably detected by mid-July (Lee and Kim, 2013). There is, as yet, no report about transmission of SYCMV; therefore, more study about SYCMV transmission in soybean will needed. However, it appears that wild legumes, including weedy soybean, may well serve as reservoirs of SYCMV and SMV in addition to their proven infection by SYMMV.

Whichever explanation is ultimately determined to explain the significant change in SMV isolate types in soybeans across all Korean provinces over a two year interval, it is clear that improving the seed health of soybeans in Korea will reduce the initial inoculum within the crop. Further surveys based on testing of self-saved seed obtained from farmers may be useful to track virus isolate types between seasons, and additional surveys of wild legumes would be useful to determine potential external sources of SMV, SYMMV and SCYMV infection. Such results would be useful to educate the typical small-scale farmer of the potential yield and quality improvements to be gained from using seed with a lower viral load, as is already widely available in the United States (Hill, 1999).

\section{ACKNOWLEDGEMENT}

This work was supported by the National Research Foundation of Korea (NRF) grant funded by the Korean Government (NRF No. 2012R1A1A2007417).

\section{REFERENCES}

Atreya, C. D., P. L. Atreya, D. W. Thornbury and T. P. Pirone 1992 Site-directed mutations in the potyvirus HC-Pro gene affect helper component activity, virus accumulation, and symptom expression in infected tobacco plants. Virology, 191(1): 106111

Atreya, C. D., B. Raccah and T. P. Pirone 1990 A point mutation in the coat protein abolish aphid transmissibility of a potyvirus. Virology, 178(1): 161-165

Berger, P. H. and T. P. Pirone 1986 The effect of helper component on the uptake and localization of potyviruses in Myzus persicae. Virology, 153: 256-261

Bergstrom, C. T., P. McElhany and L. A. Real 1999 Transmission bottlenecks as determinants of virulence in rapidly evolving pathogens. Proc. Natl. Acad. Sci. USA, 96: 5095-5100

Blanc, S., J. J. Lopez-Moya, R. Wang, S. Garcia-Lampasona, D. W. Thornbury and T. P. Pirone 1997 A specific interaction between coat protein and helper component correlates with aphid transmission of a potyvirus. Virology, 231: 141-147

Bol, J. F. 2005 Replication of alfamo- and ilarviruses: role of the coat protein. Annu. Rev. Phytopathol., 43: 39-62

Bowers, G. R. and R. M. Goodman 1991 Strain specificity of soybean mosaic virus seed transmission in soybean. Crop Sci., 31: 1171-1174

Carrington, J. C. and W. G. Dougherty 1987 Small nuclear inclusion protein encoded by a plant potyvirus genome is a protease. J. Virol., 61: 2540-2548

Carrington, J. C., S. M. Cary, T. D. Parks and W. G. Dougherty 1989 A second proteinase encoded by a plant potyvirus genome. EMBO Journal, 8: 365-370

Cho, E. K. and B. J. Chung 1976 Studies on identification and classification of soybean virus diseases I. Preliminary studies on a soybean virus disease. Korean J. Plant Prot., 15: 61-68 
Cho, S., J. Kim, M. Lim, E. Seo, S. Lim, S. M. Hong, J. S. Moon, J. Hammond and H-S. Lim 2013 Occurrence of three major soybean viruses, soybean mosaic virus, soybean yellow mottle mosaic virus and soybean yellow common mosaic virus revealed by a nationwide survey of subsistence farming soybean fields. Res. Plant Dis., 19(4): 319-325

Demski, J. W. and C. W. Kuhn 1989 Cowpea mild mottle virus. In: Compendium of soybean diseases ( ${ }^{\text {rd }}$ edition), American Phytopathological Society, St. Paul, USA, pp. 60-61

Diaz-Ruiz, J. R. and J. M. Kaper 1983 Nucleotide sequence relationships among thirty peanut stunt virus isolates determined by competition hybridization. Arch. Virol., 75: $277-$ 281

Domier, L. L., I. J. Latorre, T. A. Steinlage, N. McCoppin and G. L. Hartman 2003 Variability and transmission by Aphis glycines of North American and Asian Soybean mosaic virus isolates. Arch. Virol., 148: 1925-1941

Domier, L. L., T. A. Steinlage, H. A. Hobbs, Y. Wang, G. HerreraRodriguez, J. S. Haudenshield, N. K. McCoppin and G. L. Hartman 2007 Similarities in seed and aphid transmission among Soybean mosaic virus isolates. Plant Dis., 91: 546550

Domier, L. L., H. A. Hobbs, N. K. McCoppin, C. R. Bowen, T. A. Steinlage, S. Chang, Y. Wang and G. L. Hartman 2011 Multiple loci condition seed transmission of Soybean mosaic virus (SMV) and SMV induced seed coat mottling in soybean. Phytopathology, 101: 750-756

Green, C. E., T. Liu, V. Montel, G. Hsiao, R. D. Lester, S. Subramaniam, S. L. Gonias and R. L. Klemke 2009 Chemoattractant signaling between tumor cells and macrophages regulates cancer cell migration, metastasis and neovascularization. PLoS One, 4(8): e6713

Hill, J. H. 1999 Soybean Mosaic Virus. In: "Compendium of Soybean Diseases"., pp. 70-71

Hull, R. 2002 Matthew's Plant Virology, $4^{\text {th }}$ edition. Academic Press

Jayaram, C., J. H. Hill and W. A. Miller 1992 Complete nucleotide sequences of two soybean mosaic virus strains differentiated by response of soybean containing the Rsv resistance gene. $J$. Gen. Virol., 73: 2067-2077

Lee, S. H. and C. S. Kim 2013 Natural hosts and disease cycle of Soybean yellow mottle mosaic virus. Res. Plant Dis., 19: 281287

Lee, Y. H., S. T. Lim, Y. N. Yoon, M. G. Jeon, H. T. Yun, J. M. Ko, S. H. Lee, K. W. Lee and I. Y. Baek 2012 Incidence of soybean viral diseases in Korea. Korea Soybean Digest, 29: 7-15

Li, S., J. S. Moon, S. H. Lee and L. L. Domier 2009 First report of Soybean yellow mottle mosaic virus in soybean in North America. Plant Disease, 93: 1214

Li, M. J., J. K. Kim, E. Y. Seo, S. M. Hong, E. I. Hwang, J. K. Moon, L. L. Domier, J. Hammond, Y. N. Youn and H. S. Lim 2013 Sequence variability in the HC-Pro coding regions of Korean soybean mosaic virus isolates is associated with differences in RNA silencing suppression. Arch. Virol, 159: 1373-1383
Lim, S. M. 1985 Resistance to soybean mosaic virus in soybeans. Phytopathology, 75: 199-201

Lim, S. T. 2013 Incidence of virus diseases on soybean breeding fields and first report of Bean common mosaic virus on soybean in Korea. Gyeongbuk National University, 630.27-13182

Mueller, E. E. and C. R. Grau 2007 Seasonal progression, symptom development, and yield effects of Alfalfa mosaic virus epidemics on soybean in Wisconsin. Plant Dis., 91: 266-272

Nam, M., J. S. Kim, S. J. Park, C. Y. Park, J. S. Lee, H. S. Choi, J. S. Kim, H. G. Kim, S. M. Lim, J. S. Moon and S. H. Lee 2011 Biological and molecular characterization of Soybean yellow common mosaic virus, a new species in the genus Sobemovirus. Virus Res., 163: 363-367

Nam, M., S. M. Kim, L. L. Domier, S. Koh, J. K. Moon, H. S. Choi, H. G., Kim, J. S. Moon and S. H. Lee 2009 Nucleotide sequence and genomic organization of a newly identified member of the genus Carmovirus, Soybean yellow mottle mosaic virus, from soybean. Arch. Virol., 154: 1679-1684

Peng, Y. H., D. Kadoury, A. Gal-On, H. Huet, Y. Wang and B. Raccah 1998 Mutations in the HC-Pro gene of zucchini yellow mosaic virus: effects on aphid transmission and binding to purified virions. J. Gen. Virol., 79: 897-904

Power, A. G. 2000 Insect transmission of plant viruses: a constraint on virus variability. Curr. Opin. Plant Biol., 3: 336340

Pruss, G., X. Ge, X. M. Shi, J. C., Carrington and V. Bowman Vance 1997 Plant viral synergism: the potyviral genome encodes a broad-range pathogenicity enhancer that transactivates replication of heterologous viruses. Plant Cell 9: 859-868

Seo, J., S. Kang, B. Y. Seo, J. K. Jung and K. Kim 2010 Mutational analysis of interaction between coat protein and helper componentproteinase of Soybean mosaic virus involved in aphid transmission. Mol. Plant Pathol., 11: 265-276

Thompson, J. D., T. J. Gibson, F. Plewniak, F. Jeanmougin and D. G. Higgins 1997 The CLUSTAL X windows interface: flexible strategies for multiple sequence alignment aided by quality analysis tools. Nucleic Acid Res., 25: 4876-4882

Tamura, K., D. Peterson, N. Perterson, G. Stecher, M. Nei and S. Kumar 2011 MEGA5: molecular evolutionary genetics analysis using maximum likelihood, evolutionary distance, and maximum parsimony methods. Mol. Biol. Evol., 28: 2731-2739

Terauchi, H., S. Kanematsu, K. Honda, Y. Mikoshiba, K. Ishiguro and S. Hidaka 2001 Comparison of complete nucleotide sequences of genomic RNAs of four Soybean dwarf virus strains that differ in their vector specificity and symptom production. Arch. Virol. 146: 1885-1898

Urcuqui-Inchima, S., A. Haenni and F. Bernardi 2001 Potyvirus proteins: a wealth of functions. Virus Res., 74: 157-175

Van Regenmortel, M. H. V., C. M. Faquet, D. H. L. Bishop, E Carstens, M. Estes and S. Lemon 2000 Virus Taxonomy: Seventh Report of the International Committee on Taxonomy of Viruses, Academic Press, San Diego 